\title{
Efektivitas Jenis Koagulan Poly Aluminium Chloride Menurut Variansi Dosis dan Waktu Pengadukan terhadap Penurunan Parameter Limbah Cair Industri Tahu
}

\author{
Bambang Murwanto \\ Jurusan Kesehatan Lingkungan, Politeknik Kesehatan Tanjung Karang, Indonesia \\ Email: bam9murwanto@gmail.com
}

\begin{abstract}
Effectiveness of Coagulant Type Poly Aluminium Chloride According to Dosage Variance and Stirring Time to Decrease Parameter of Tofu Industrial Liquid Waste. Tofus industry is a business built in the framework of the development of activities in the field of food that has a positive and negative impact on the environment. The negative impact of the tofus industry in the form of waste disposal that causes pollution problems that damage the environment Pollution environment. The result of solid waste (tofus waste) and liquids waste. Most of the liquid wastes produced by the tofu manufacture industry are viscous liquids that are separated from the clump of tofu called whey. Objective: To determine the effect of Coagulant PAC (Polyaluminium Chloride) with dose of $75 \mathrm{mg} / 1,150 \mathrm{mg} / 1,225 \mathrm{mg} / 1,300 \mathrm{mg} / 1$ and slow stirring time 10 minutes, 15 minutes, 20 minutes and 25 minutes in BOD parameters, COD and TSS liquid waste tofu. This type of research is a real experiment with a Pretest-Postest Research with A Control Group Design. this study can be performed using PAC as a coagulant with a dose and slow stirring time which is effective in lowering BOD, COD and TSS levels in tofus wastewater. The research was conducted at Integrated Laboratory of Poltekkes Tanjungkarang and samples were taken were tofus waste in Kelurahan Gunung Sulah Bandar Lampung. The population in this study is the tofus waste generated from the tofu industry in Kelurahan Gunung Sulah. Samples taken in this study are liquid waste generated from the tofu industry in Kelurahan Gunung Sulah Bandar Lampung, taken early morning around 09.00 WIB. The results of this study contain an effective compound of administration of Polyalumunium Chloride (PAC), for all parameters of industrial waste know BOD, COD, and TSS, in accordance with Regulation of Minister of Environment No. 5 years 2014 is $765 \mathrm{mg} / 1$, with a stirring time of 25 minutes.
\end{abstract}

Keywords: PAC (Polyaluminium Chloride), BOD, COD, TSS

\begin{abstract}
Abstrak: Efektivitas Jenis Koagulan Poly Aluminium Chloride Menurut Variansi Dosis dan Waktu Pengadukan terhadap Penurunan Parameter Limbah Cair Industri Tahu. Industri tahu merupakan usaha yang didirikan dalam rangka pengembangan kegiatan di bidang pangan yang mempunyai dampak positif dan negatif bagi lingkungan. Dampak negatif dari industri tahu berupa limbah buangan yang menimbulkan masalah pencemaran sehingga merusak lingkungan. Pencemaran lingkungan tersebut berupa hasil pembuangan limbah padat (ampas tahu) dan limbah cair. Sebagian besar limbah cair yang dihasilkan oleh industri pembuatan tahu adalah cairan kental yang terpisah dari gumpalan tahu yang disebut air dadih. Tujuan penelitian untuk mengetahui pengaruh Koagulan PAC (Polyaluminium Chloride) dengan dosis $75 \mathrm{mg} / \mathrm{l}, 150 \mathrm{mg} / \mathrm{l}, 225 \mathrm{mg} / \mathrm{l}$, $300 \mathrm{mg} / \mathrm{l}$ dan waktu pengadukan lambat 10 menit, 15 menit, 20 menit dan 25 menit dalam menurunkan parameter BOD, COD dan TSS limbah cair industri tahu. Jenis penelitian ini adalah eksperimen sungguhan dengan rancangan penelitian pretest-posttest with control group (rancangan pretest-postest dengan kelompok kontrol). Penelitian ini meneliti kemampuan PAC sebagai koagulan dengan dosis dan waktu pengadukan lambat yang efektif dalam menurunkan kadar BOD, COD dan TSS dalam limbah cair tahu. Penelitian dilaksanakan di Laboratorium Terpadu Poltekkes Tanjungkarang dan sampel yang diambil adalah limbah cair industri tahu di Kelurahan Gunung Sulah Bandarlampung. Populasi dalam penelitian ini adalah limbah tahu yang dihasilkan dari industri tahu di Kelurahan Gunung Sulah. Sampel yang diambil dalam penelitian ini adalah limbah cair tahu yang dihasilkan dari industri tahu di Kelurahan Gunung Sulah Bandar Lampung, diambil pagi hari sekitar jam 09.00 WIB. Hasil penelitian ini menyimpulkan bahwa kadar efektif pemberian Polyalumunium Chloride (PAC), untuk semua parameter limbah industri tahu BOD, COD dan TSS, sesuai dengan Peraturan Menteri Lingkungan Hidup No. 5 tahun 2014 adalah 765 $\mathrm{mg} / \mathrm{l}$, dengan waktu pengadukan 25 menit.
\end{abstract}

Kata kunci: PAC (Polyaluminium Chloride), BOD, COD, TSS 
Industri tahu merupakan usaha yang didirikan dalam rangka pengembangan kegiatan di bidang pangan yang mempunyai dampak positif dan negatif bagi lingkungan. Dampak positif berupa pemenuhan kebutuhan masyarakat akan sumber pangan sedangkan dampak negatif dari industri tahu berupa limbah buangan yang menimbulkan masalah pencemaran sehingga merusak lingkungan. Pencemaran lingkungan tersebut berupa hasil pembuangan limbah padat (ampas tahu) dan limbah cair. Sebagian besar limbah cair yang dihasilkan oleh industri pembuatan tahu adalah cairan kental yang terpisah dari gumpalan tahu yang disebut air dadih. Semakin tinggi produksi tahu tentunya menghasilkan limbah yang tinggi pula. Sedangkan limbah cairnya dihasilkan dari proses pencucian, perebusan, pengepresan dan pencetakan tahu. Pengolahan $1 \mathrm{~kg}$ kacang kedelai menjadi tahu akan menghasilkan limbah cair sebanyak 15-20 liter (Sadzali, 2010).

Pengolahan limbah yang cukup murah dan aman adalah pengolahan secara kimia dengan koagulasi. Koagulasi yaitu proses pencampuran koagulan (bahan kimia) atau pengendap ke dalam air baku dengan kecepatan perputaran yang tinggi dalam waktu yang singkat. Poly Alumunium Chloride (PAC) merupakan salah satu pengganti alum padat yang efektif karena menghasilkan koagulasi air dengan kekeruhan yang berbeda dengan cepat, menggenerasi lumpur lebih sedikit, dan juga meninggalkan lebih sedikit residu alumunium pada air yang diolah (Malhotra, 1994 dalam Kristijarti dkk, 2013). Menurut Echanpin (2005) dalam Said (2009), Poly Alumunium Chloride (PAC) memiliki kelebihan dengan tingkat adsorpsi yang kuat, mempunyai kekuatan lekat, tingkat pembentukan flok-flok tinggi meski dengan dosis kecil, memiliki tingkat sedimentasi yang cepat, cakupan penggunaannya luas, dan konsumsinya cukup pada konsentrasi rendah.

Hasil penelitian yang dilakukan oleh A. prima Kristijarti, dkk (2013) Percobaan koagulasi-flokulasi dalam pengolahan air limbah pabrik jamu di PT X dengan PAC menghasilkan hasil yang lebih baik daripada dengan $\mathrm{FeSO}_{4}$. Dosis PAC yang menyebabkan penyisihan paling tinggi adalah $0,163 \mathrm{~g} / \mathrm{l}$ mencapai nilai $99,24 \%$.

Data yang di dapat dari penelitian yang dilakukan oleh Muhammad Tomi Bastian (2016) rerata kadar COD pada limbah tahu di Kelurahan Gunung Sulah adalah $4000 \mathrm{mg} / \mathrm{L}$ dan rerata TSS sebesar $1150 \mathrm{mg} / \mathrm{L}$, bila di bandingkan dengan baku mutu air limbah menurut Peraturan Mentri
Lingkungan Hidup N0.5 tahun 2014 COD sebesar $150 \mathrm{mg} / \mathrm{l}$ dan TSS sebesar $200 \mathrm{mg} / \mathrm{L}$ kadar COD dan TSS limbah tahu di Kelurahan Gunung Sulah telah melebihi baku mutu.

Beberapa hasil penelitian tentang efektifitas PAC dengan beberapa variansi dosis dan waktu pengenceran. Di Iran, Mirzaiy, A. dkk (2012) menggunakan PAC untuk mengetahui perubahan tingkat kegumpalan, bahan-bahan organik, coliform dan Bakteri Hetrotropik di Sungai Karoon, Iran dengan variansi dosis 3, 5, 8, 10, 20,30, 40, 50 mg/l. Wang, J. dkk. (2014) menggunakan waktu putar koagulan PAC dalam penurunan kadar fosfor masing 40 detik, 5, 10, 20 Menit. Di India Moorthy, D.V.S., dan Babu, R., (2010) menggunakan variansi dengan rentang waktu 1 menit sampai 15 menit untuk pengadukan campuran dengan kecepetan 25 sampai $30 \mathrm{rpm}$, dalam menurunkan COD sebagai pewarna reaktif. Demikian pula dalam pengolahan air limbah pada kualitas efluen dari pengolahan air limbah domestik, menggunakan waktu pengadukan selama masing $0,5,10$, dan 20 menit (Nansubunga, I., dkk, 2013). Oleh sebab itu maka penulis dalam penelitian ini akan mencoba efektifitas PAC terhadap limbah pabrik tahu dengan variansi dosis $75 \mathrm{mg} / \mathrm{l}, 150 \mathrm{mg} / \mathrm{l}$, $225 \mathrm{mg} / \mathrm{l}$ dan $300 \mathrm{mg} / \mathrm{l}$ serta variansi waktu 10 menit, 15 menit, 20 menit, dan 25 menit.

Berdasarkan permasalahan tersebut peneliti ingin mencoba melakukan efisiensi pemisahan dengan bahan kimia untuk menurunkan parameter pencemaran air limbah tahu. Penelitian yang dilakukan berskala laboratorium dengan mempertimbangkan harga, kemudahan penanganan dan penyimpanan, dan ketersediaan di pasar, Polyaluminium Chloride (PAC) dipilih sebagai koagulan. Oleh karena itu, perlu dicari dosis koagulan yang terefektif pada koagulan tersebut mampu memberikan efektivitas koagulasi yang terebaik jika tercapai dosis yang terefektif juga. Selanjutnya dilakukan analisa parameter BOD (biochemical oksygen demand ), COD (Chemical Oxygen Demand), TSS (Total Suspended Solid).

Berdasarkan uraian latar belakang di atas permasalahan yang dapat dikemukakan adalah "Apakah koagulan PAC efektif untuk menurunkan parameter BOD, COD, TSS limbah cair tahu dengan variansi dosis $75 \mathrm{mg} / \mathrm{l}$, $150 \mathrm{mg} / \mathrm{l}, 225 \mathrm{mg} / \mathrm{l}$ dan $300 \mathrm{mg} / \mathrm{l}$ serta variansi waktu 10 menit, 15 menit, 20 menit, dan 25 menit?" 


\section{METODE}

Desain penelitian ini eksperimen sungguhan (Pre-Post Test Experiment) dengan rancangan penelitian Control Time Series Desaign (Rancangan Rangkaian Waktu Dengan Kelompok Kontrol/Pembanding) (Notoadmodjo, 1993.

Penelitian ini meneliti kemampuan PAC sebagai koagulan dengan dosis dan waktu pengadukan lambat yang efektif dalam menurunkan kadar BOD, COD dan TSS dalam limbah cair tahu. Jumlah sampel yang diambil pada penelitian ini digambarkan dalam tabel berikut:

Tabel 1. Jumlah Konsentrasi Sampel Eksperimen Menurut Waktu

\begin{tabular}{ccccc}
\hline \multirow{2}{*}{ Waktu } & \multicolumn{4}{c}{ Dosis } \\
\cline { 2 - 5 } & PAC 75 mg/l & PAC 150 mg/l & PAC 225 mg/l & PAC 300 mg/l \\
\hline 10 menit & $10 ; 75$ & $10 ; 150$ & $10 ; 225$ & $10 ; 300$ \\
\hline 15 menit & $15 ; 75$ & $15 ; 150$ & $15 ; 225$ & $15 ; 300$ \\
\hline 20 menit & $20 ; 75$ & $20 ; 150$ & $20 ; 225$ & $20 ; 300$ \\
\hline 25 menit & $25 ; 75$ & $25 ; 150$ & $25 ; 225$ & $25 ; 300$ \\
\hline
\end{tabular}

Tabel 2. Jumlah Konsentrasi Kelompok Kontrol Menurut Waktu

\begin{tabular}{lc}
\hline \multirow{2}{*}{ Waktu } & Dosis \\
\cline { 2 - 2 } & PAC 0 $\mathbf{~ m g} / \mathbf{l}$ \\
\hline 10 menit & $10 ; 0$ \\
\hline 15 menit & $15 ; 0$ \\
\hline 20 menit & $20 ; 0$ \\
\hline 25 menit & $25 ; 0$ \\
\hline
\end{tabular}

Penelitian dilaksanakan di Laboratorium Terpadu Poltekkes Tanjungkarang dan sampel yang diambil adalah limbah cair industri tahu di Kelurahan Gunung Sulah Bandar Lampung. Penelitian ini dilakukan pada bulan Mei 2017 yang dilanjutkan dengan pengolahan data dan penyusunan laporan akhir. Populasi dalam penelitian ini adalah limbah tahu yang dihasilkan dari industri tahu di Kelurahan Gunung Sulah. Sampel yang diambil dalam penelitian ini adalah limbah cair tahu yang dihasilkan dari industri tahu di Kelurahan Gunung Sulah Bandar Lampung, diambil pagi hari sekitar jam 09.00 WIB. Pengulangan atau replikasi dalam penelitian ini dihitung melalui rumus (Supriyadi, 2014).

$(\mathrm{r}-1)(\mathrm{t}-1) \geq 15$

$(\mathrm{r}-1)(16-1) \geq 15$

$(\mathrm{r}-1)(15) \geq 15$

$15 r-15 \geq 15$

$15 \mathrm{r} \geq 15+15$

$15 r \geq 30$

$r \geq 30 / 15$

$r \geq 2$

Dengan: $r=j u m l a h$ replikasi atau pengulangan; $\mathrm{t}=\mathrm{jumlah}$ perlakuan atau treatment; dengan menggunakan rumus tersebut di dapat pengulangan sebanyak 2 kali.

Analisis Data dilakukan dengan analisis univariat dan bivariat. Analisis univariat digunakan untuk mendeskripsikan masingmasing variabel penelitian dan persentase penurunan kadar BOD, COD dan TSS. Analisis yang digunakan yaitu mean dan range dalam bentuk. Analisis bivariat digunakan untuk mengetahui jenis koagulan dan waktu pengadukan lambat yang efektif serta apakah terdapat perbedaan rata-rata antara variabel independen terhadap variabel dependen, yang kemudian disimpulkan bahwa variabel independen mempengaruhi variabel dependen. Analisis menggunakan uji Anova.

\section{HASIL}

\section{A. ANALISIS UNIVARIAT}

Dari hasil pemeriksaan sampel limbah cair tahu replikasi ke-1 05 September 2017 yang dilakukan pada tanggal dan replikasi ke-2 yang dilakukan pada tanggal 06 September 2017. Diperoleh hasil pemeriksaan sampel limbah cair tahu sebelum perlakuan (pre-test) dan setelah perlakuan (post-test), dengan perlakuan penambahan Koagulan PAC (Polyaluminium Chloride) dengan dosis $75 \mathrm{mg} / \mathrm{l}, 150 \mathrm{mg} / \mathrm{l}, 225$ $\mathrm{mg} / \mathrm{l}, 300 \mathrm{mg} / \mathrm{l}$ dan Waktu kontak 10 menit, 15 menit, 20 menit dan 25 menit dalam menurunkan parameter COD dan TSS limbah cair industri tahu.

Proses koagulasi dimulai dengan pengadukan cepat selama 1 menit dengan kecepatan $120 \mathrm{rpm}$, dilanjutkan pengadukan lambat dengan kecepatan 40-50 rpm dengan waktu yang ditentukan dalam penelitian ini yaitu 10 menit, 15 menit, 20 menit dan 25 menit. Proses pengadukan cepat bertujuan untuk mendispersikan koagulan dengan air limbah agar dapat bercampur dengan sempurna. Sedangkan 
pengadukan lambat ditujan untuk membantu pembentukan flok-flok dengan ukuran lebih besar. Hingga saat pengendapan dapat mengendap secara sempurna.

Hasil pemeriksaan fisik sampel air limbah tahu sesudah penambahan PAC (Pollyalumunium Chloride) warna air limbah berwarna kuning dengan kuning semakin pekat jika dosis yang ditambahkan semakin banyak. Aroma air limbah seperti aroma PAC (Pollyalumunium Chloride).

Hasil pengukuran $\mathrm{pH}$ limbah cair tahu sebelum perlakuan sebesar 5,00. Setelah perlakuan koagulasi kadar $\mathrm{pH}$ pada limbah cair tahu sebesar 4,35. Hasil pengukuran suhu pada penelitian ini tidak mengalami penurunan maupun peningkatan. Suhu sebelum perlakuan $28^{\circ} \mathrm{C}$ dan hasil pengukuran yang sama didapat setelah perlakuan koagulasi.

Pada waktu pengadukan 10 menit pembentukan flok relatif kecil, dengan penambahan waktu pengadukan terlihat ukuran flok yang semakin besar setiap 5 menit penambahan waktu pengadukan lambat hingga menit ke 25 bentuk flok semakin besar

Penambahan dosis pada dosis $75 \mathrm{mg} / \mathrm{l}$ hasil endapan yang dihasilkan lebih sedikit dibandingkan dengan dosis 150, 225, $300 \mathrm{mg} / \mathrm{l}$, yang artinya semakin banyak penambahan dosis pada penelitian ini maka endapan/lumpur yang dihasilkan semakin banyak, maka didapatkan hasil pemeriksaan sampel penelitian disajikan dalam data berikut :

1. Hasil kadar BOD sebelum dan sesudah pemberian PAC berdasarkan Variabel Dosis dan Waktu.

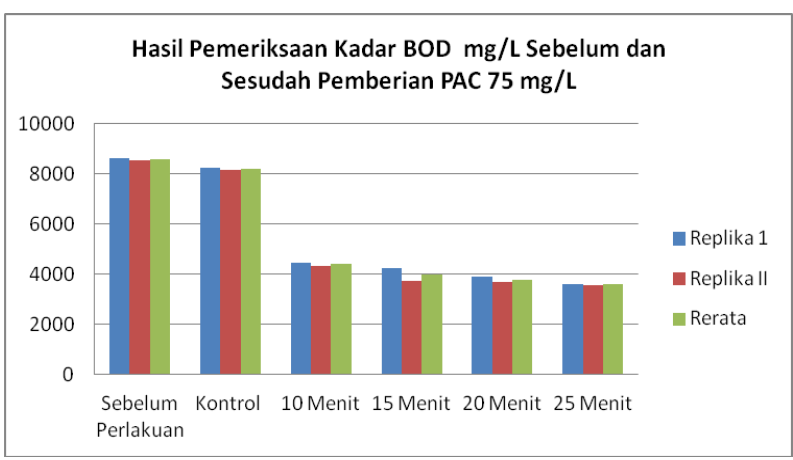

Gambar 1. Hasil Pemeriksaan Kadar BOD (mg/L), Sebelum dan Sesudah Pemberian PAC 75 mg/L

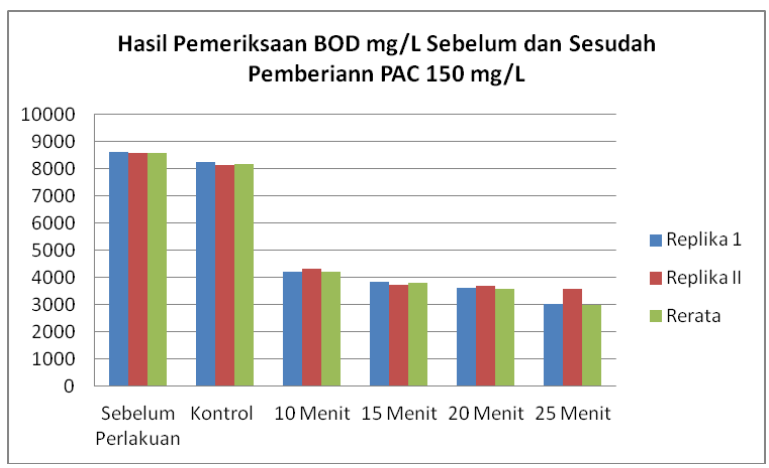

Gambar 2. Hasil Pemeriksaan Kadar BOD $(\mathrm{mg} / \mathrm{L})$, Sebelum dan Sesudah Pemberian PAC $150 \mathrm{mg} / \mathrm{L}$

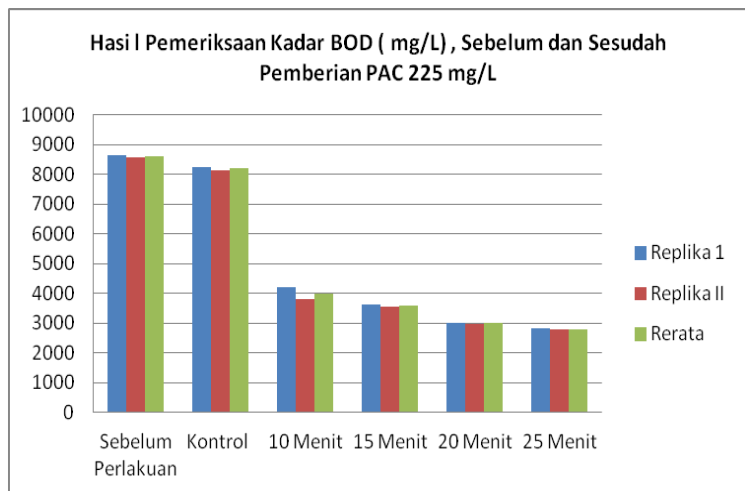

Gambar 3. Hasil Pemeriksaan Kadar BOD (mg/L), Sebelum dan Sesudah Pemberian PAC $225 \mathrm{mg} / \mathrm{L}$

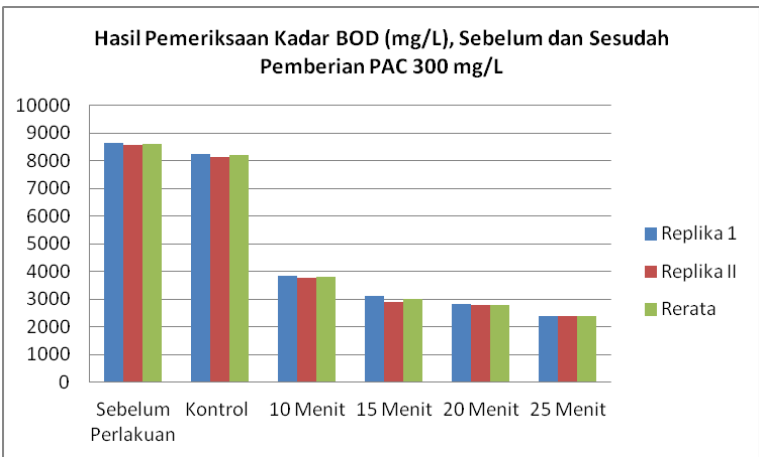

Gambar 4. Hasil Pemeriksaan Kadar BOD (mg/L), Sebelum dan Sesudah Pemberian PAC 300 mg/L 
Dari hasil pemeriksaan sebanyak dua kali tersebut, diambil rata-ratanya, yang secara lengkap pada Tabel 3 di bawah ini.

\begin{tabular}{lcccc} 
Tabel 3. Rata-rata & \multicolumn{2}{c}{ Kadar } & BOD \\
Berdasarkan & Variabel Dosis & PAC \\
Pada Limbah Cair Tahu & \\
\hline Perlakuan & $\begin{array}{c}\text { PAC } \\
\mathbf{7 5} \\
\text { mg/l }\end{array}$ & $\begin{array}{c}\text { PAC } \\
\mathbf{1 5 0} \\
\text { mg/l }\end{array}$ & $\begin{array}{c}\text { PAC } \\
\mathbf{2 2 5} \mathbf{~ m g / l}\end{array}$ & $\begin{array}{c}\text { PAC } \\
\mathbf{3 0 0} \\
\mathbf{m g} / \mathbf{l}\end{array}$ \\
\hline $\begin{array}{l}\text { Sebelum } \\
\text { Perlakuan }\end{array}$ & 8600 & 8600 & 8600 & 8600 \\
\hline Kontrol & 8198 & 8198 & 8198 & 8198 \\
\hline 10 Menit & 4400 & 4200 & 4000 & 3800 \\
\hline 15 Menit & 4000 & 3800 & 3600 & 3000 \\
\hline 20 Menit & 3800 & 3600 & 3000 & 2800 \\
\hline 25 Menit & 3600 & 3000 & 2800 & 2400 \\
\hline
\end{tabular}

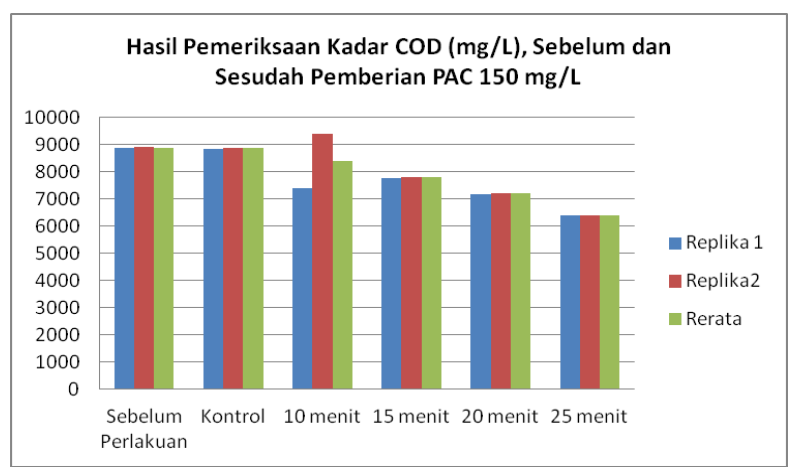

Gambar 6. Hasil Pemeriksaan Kadar COD $(\mathrm{mg} / \mathrm{L})$, Sebelum dan Sesudah Pemberian PAC $150 \mathrm{mg} / \mathrm{L}$

Hasil tabel 3 diperoleh rata-rata kadar COD berdasarkan dosis penambahan PAC (Pollyalumunium Chloride) tanpa memperhitungkan waktu pengadukan, rata-rata kadar BOD pada kelompok kontrol sebesar 8198 dengan persentase penurunan $4,6 \%$. Sedangkan pada penambahan dosis dengan hasil persentase terendah 42,63\% yaitu pada dosis $300 \mathrm{mg} / \mathrm{l}$ dengan lama pengadukan selama 25 menit dengan rata-rata kadar BOD sebesar 4400 ppm. Hasil persentase tertinggi 70,7\% yaitu pada dosis $300 \mathrm{mg} / \mathrm{l}$ dengan rata-rata kadar BOD $2400 \mathrm{mg} / \mathrm{l}$.

\section{Hasil kadar COD Sebelum dan Sesudah} Perlakuan Pemberian PAC Berdasarkan Dosis Waktu Pengadukan

Dari hasil pemeriksaan kadar COD (mg/L) tergambar sebelum dan sesudah pemberian PAC berdasarkan variansi dosis dan waktu pengadukan melalui dua kali pemeriksaan (Replika 1 dan Replika 2), seperti pada gambar grafik berikut di bawah ini.

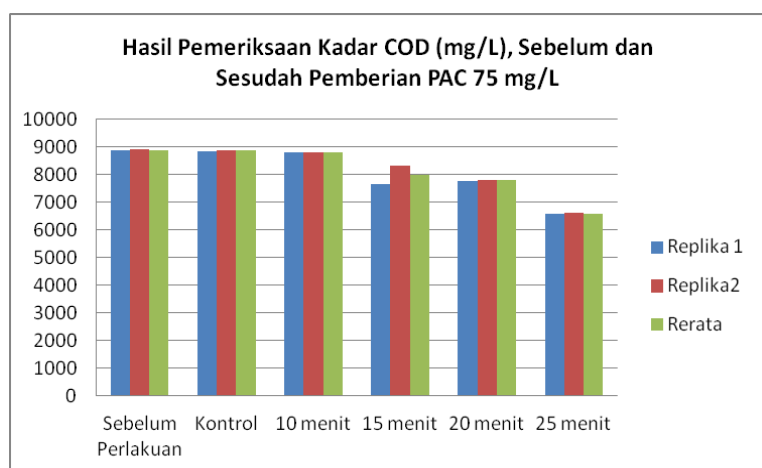

Gambar 5. Hasil Pemeriksaan Kadar COD $(\mathrm{mg} / \mathrm{L})$ Sebelum dan Sesudah Pemberian PAC $75 \mathrm{mg} / \mathrm{L}$ 
Tabel 4. Rata-rata kadar COD berdasarkan Variabel dosis dan waktu Pengadukan Pada Limbah Cair Tahu

\begin{tabular}{ccccc}
\hline Perlakuan & $\begin{array}{c}\text { PAC 75 } \\
\mathbf{m g} / \mathbf{l}\end{array}$ & $\begin{array}{c}\text { PAC } \\
\mathbf{1 5 0} \\
\mathbf{m g} / \mathbf{l}\end{array}$ & $\begin{array}{c}\text { PAC } \\
\mathbf{2 2 5} \\
\mathbf{m g} / \mathbf{l}\end{array}$ & $\begin{array}{c}\text { PAC } \\
\mathbf{3 0 0} \\
\mathbf{m g} / \mathbf{l}\end{array}$ \\
\hline $\begin{array}{c}\text { Sebelum } \\
\text { Perlakuan }\end{array}$ & 8900 & 8900 & 8900 & 8900 \\
\hline Kontrol & 8876 & 8876 & 8876 & 8876 \\
\hline 10 menit & 8800 & 8400 & 8000 & 7800 \\
\hline 15 menit & 8000 & 7800 & 7600 & 7200 \\
\hline 20 menit & 7800 & 7200 & 7000 & 6800 \\
\hline 25 menit & 6600 & 6400 & 6000 & 5600 \\
\hline
\end{tabular}

Hasil tabel 4 diperoleh rata-rata kadar COD berdasarkan waktu pengadukan lambat tanpa memperhitungkan penambahan dosis PAC (Pollyalumunium Chloride) rata-rata kadar COD pada kelompok kontrol sebesar 8876 dengan persentase penurunan $0,26 \%$. Sedangkan pada hasil persentase terendah yaitu $0,86 \%$ pada waktu pengadukan 10 menit dengan rata-rata kadar COD sebesar 8800 ppm. Hasil persentase tertinggi yaitu $36,36 \%$ pada waktu pengadukan 25 menit dengan pemberian PAC $300 \mathrm{mg} / \mathrm{l}$ maka rata-rata kadar COD $5600 \mathrm{mg} / \mathrm{l}$.

3. Hasil kadar TSS Sebelum dan Sesudah Perlakuan Pemberian PAC Berdasarkan Dosis Waktu Pengadukan

Dari hasil pemeriksaan kadar TSS (mg/L) tergambar sebelum dan sesudah pemberian PAC berdasarkan variansi dosis dan waktu pengadukan melalui dua kali pemeriksaan (Replika 1 dan Replika 2), seperti pada gambar grafik berikut di bawah ini.

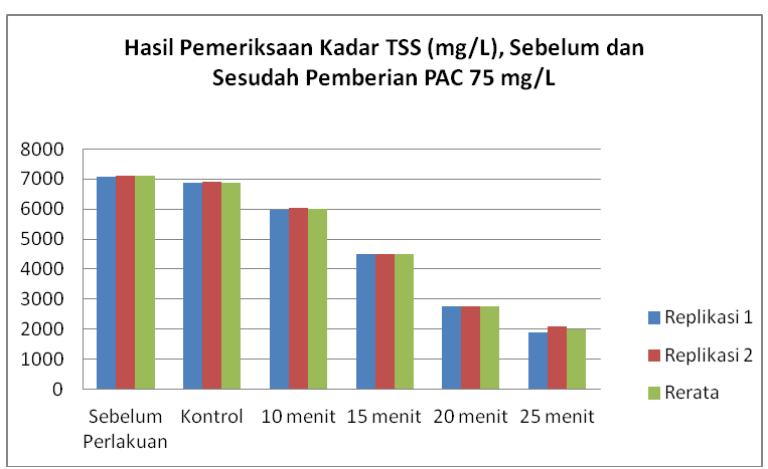

Gambar 9. Hasil Pemeriksaan Kadar TSS $(\mathrm{mg} / \mathrm{L})$, Sebelum dan Sesudah Pemberian PAC 75 mg/L

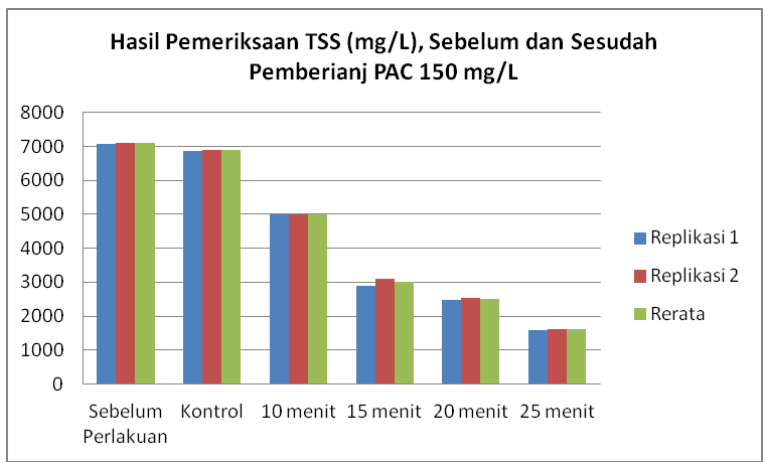

Gambar 10. Hasil Pemeriksaan Kadar TSS (mg/L), Sebelum dan Sesudah Pemberian PAC $150 \mathrm{mg} / \mathrm{L}$

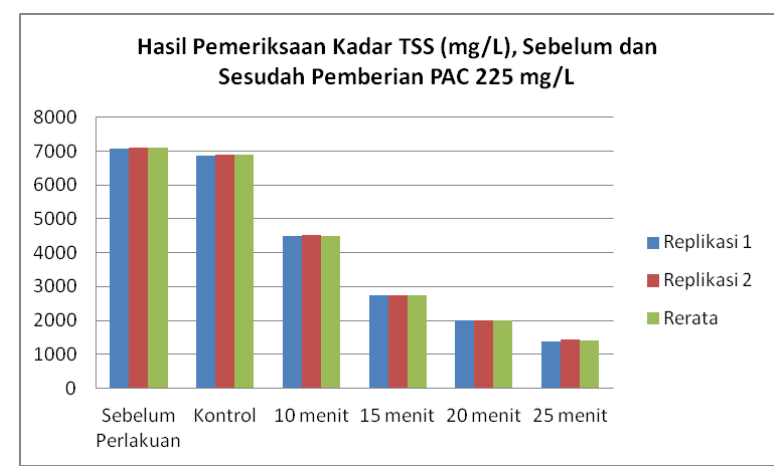

Gambar 11. Hasil Pemeriksaan Kadar TSS (mg/L), Sebelum dan Sesudah Pemberian PAC $225 \mathrm{mg} / \mathrm{L}$

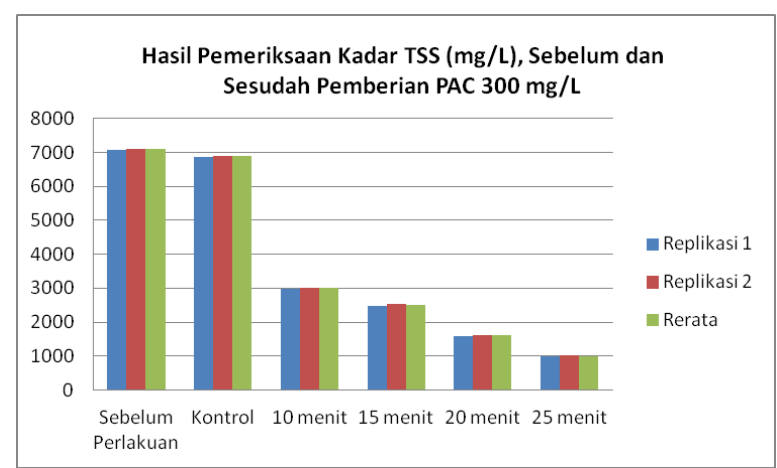

Gambar 12. Hasil Pemeriksaan Kadar TSS (mg/L), Sebelum dan Sesudah Pemberian PAC 300mg

Dari hasil pemeriksaan sebanyak dua kali tersebut, diambil reratanya, yang secara lengkap pada Tabel 5. 
Tabel 5. Rata-rata kadar TSS berdasarkan Variabel dosis dan waktu Pengadukan Pada Limbah Cair Tahu

\begin{tabular}{lcccc}
\hline Perlakuan & $\begin{array}{c}\text { PAC 75 } \\
\text { mg/l }\end{array}$ & $\begin{array}{c}\text { PAC } \\
\mathbf{1 5 0} \\
\mathbf{m g} / \mathbf{l}\end{array}$ & $\begin{array}{c}\text { PAC } \\
\mathbf{2 2 5} \\
\mathbf{m g} / \mathbf{l}\end{array}$ & $\begin{array}{c}\text { PAC } \\
\mathbf{3 0 0} \\
\mathbf{m g} / \mathbf{l}\end{array}$ \\
\hline $\begin{array}{l}\text { Sebelum } \\
\text { Perlakuan }\end{array}$ & 7100 & 7100 & 7100 & 7100 \\
\hline Kontrol & 6890 & 6890 & 6890 & 6890 \\
\hline 10 menit & 6005 & 5000 & 4500 & 3000 \\
\hline 15 menit & 4500 & 3000 & 2750 & 2500 \\
\hline 20 menit & 2750 & 2500 & 2000 & 1600 \\
\hline 25 menit & 2000 & 1600 & 1400 & 1000 \\
\hline
\end{tabular}

Hasil tabel 5 diperoleh rata-rata kadar TSS berdasarkan waktu pengadukan lambat tanpa memperhitungkan penambahan dosis PAC (Pollyalumunium Chloride) rata-rata kadar TSS pada kelompok kontrol sebesar 6890 ppm dengan persentase penurunan $2,95 \%$. Sedangkan pada hasil persentase terendah yaitu $5,66 \%$ pada waktu pengadukan 10 menit dengan rata-rata kadar TSS sebesar $6005 \mathrm{ppm}$. Hasil persentase tertinggi yaitu $85,48 \%$ pada waktu pengadukan 25 menit dengan pemberian PAC $300 \mathrm{mg} / \mathrm{l}$ maka rata-rata kadar TSS 1000 mg/l.

\section{B. ANALISIS BIVARIAT}

Dalam menganalisis pengaruh pemberian PAC ini peneliti menggunakan uji perbedaan Analisis Varian atau Anova Satu Jalan secara bertahap mulai dari uji Anova perkelompok variabel BOD, COD dan TSS. Kemudian diteruskan menguji Anava antara kelompok tersebut secara keseluruhan dari masing-masing kandidat hasil seleksi yang paling efektif.

\section{Pengaruh Variabel Dosis terhadap Penurunan Kadar BOD}

Hasil uji Anava penurunan kadar BOD dengan uji Anava secara secara singkat hasil akhirnya seperti pada tabel 6 berikut ini.

Tabel 6. Tabel Anova Satu Jalan Hasil Tes Variabel Dosis dan Waktu Pengadukan terhadap Penurunan Kadar BOD Pada Limbah Cair Tahu

\begin{tabular}{lrrrrr}
\hline $\begin{array}{l}\text { Sumber } \\
\text { Varians }\end{array}$ & db & RJK & Fhitung & $\begin{array}{c}\text { Ftabel } \\
(\boldsymbol{\alpha}=\mathbf{0 , 0 5})\end{array}$ \\
\cline { 1 - 2 } $\begin{array}{l}\text { Antar } \\
\text { Kelompok }\end{array}$ & 3 & 662.500 & & \\
\cline { 1 - 2 } $\begin{array}{l}\text { Dalam } \\
\text { Kelompok }\end{array}$ & 12 & $704.888,8$ & & & 3,94 \\
\hline
\end{tabular}

Dari Tabel 6 tergambar bahwa Fhitung <FTabel, dengan taraf signifikasi $0,05 \%$ dengan Derajat Kebebasan Antar Kelompok
(Pembilang) yaitu $\mathrm{dk}=\mathrm{k}-1=4-1=3$, dan Varian dalam kelompok, $\mathrm{dk}=\mathrm{N}-\mathrm{k}=16-4=12$, maka $\mathrm{H} 0$ diterima atau dengan kata lain tidak ada perbedaan yang bermakna dari variansi kadar penurunan BOD tersebut. Sehingga kadar yang dianggap efisien adalah $300 \mathrm{mg} / \mathrm{l}$.

\section{Pengaruh Variabel Dosis PAC terhadap Penurunan Kadar COD.}

Hasil uji Anova penurunan kadar COD dengan uji Anava singkat hasil akhirnya seperti pada tabel 7 berikut ini.

Tabel 7. Hasil Tes Variabel Dosis dan Waktu Pengadukan terhadap Penurunan Kadar COD Pada Limbah Cair Tahu

\begin{tabular}{lrcrr}
\hline $\begin{array}{l}\text { Sumber } \\
\text { Varians }\end{array}$ & db & RJK & Fh & $\begin{array}{c}\text { Ftabel } \\
(\mathbf{a}=\mathbf{0 , 0 5})\end{array}$ \\
\cline { 1 - 2 } $\begin{array}{l}\text { Antar } \\
\text { Kelompok }\end{array}$ & 3 & 2.650 .000 & & \\
\cline { 1 - 2 } $\begin{array}{l}\text { Dalam } \\
\text { Kelompok }\end{array}$ & 12 & $7.957,291,7$ & & 3,88 \\
\hline
\end{tabular}

Dari Tabel 7 tergambar bahwa Fhitung<FTabel, dengan taraf signifikasi $0,05 \%$ dengan Derajat Kebebasan Antar Kelompok (Pembilang) yaitu $\mathrm{dk}=\mathrm{k}-1=4-1=3$, dan Varian dalam kelompok, $\mathrm{dk}=\mathrm{N}-\mathrm{k}=16-4=12$, maka $\mathrm{H} 0$ diterima atau dengan kata lain tidak ada perbedaan yang bermakna dari variansi kadar penurunan COD tersebut. Sehingga kadar yang dianggap efisien adalah $300 \mathrm{mg} / \mathrm{l}$.

\section{Pengaruh Variabel Waktu Pengadukan terhadap Penurunan Kadar TTS}

Hasil uji Anava penurunan kadar TSS dengan uji Anava singkat hasil akhirnya seperti pada tabel 8 berikut ini.

Tabel 8. Tabel Anava Satu Jalan Hasil Tes Variabel Dosis dan Waktu Pengadukan terhadap Penurunan Kadar TSS Pada Limbah Cair Tahu

\begin{tabular}{|c|c|c|c|c|}
\hline $\begin{array}{l}\text { Sumber } \\
\text { Varians }\end{array}$ & db & RJK & Fh & $\begin{array}{c}\text { Ftabel } \\
(\alpha=0,05)\end{array}$ \\
\hline $\begin{array}{l}\text { Antar } \\
\text { Kelompok }\end{array}$ & 3 & $637.812,5$ & \multirow{2}{*}{1,3} & \multirow{2}{*}{3,88} \\
\hline $\begin{array}{l}\text { Dalam } \\
\text { Kelompok }\end{array}$ & 12 & $704.888,8$ & & \\
\hline
\end{tabular}

Dari Tabel 8 tergambar bahwa Fhitung <FTabel, dengan taraf signifikasi 0,05\% dengan Derajat Kebebasan Antar Kelompok (Pembilang) yaitu $\mathrm{dk}=\mathrm{k}-1=4-1=3$, dan Varian dalam kelompok, $\mathrm{dk}=\mathrm{N}-\mathrm{k}=16-4=12$, maka $\mathrm{H} 0$ diterima atau dengan kata lain tidak ada perbedaan yang bermakna dari variansi kadar 
penurunan TSS tersebut. Sehingga kadar yang dianggap efisien adalah $300 \mathrm{mg} / \mathrm{l}$.

\section{Pengaruh Variabel Waktu Pengadukan dan Dosis PAC terhadap Penurunan Kadar Variabel BOD, COD dan TSS}

Hasil uji Anava penurunan kadar BOD, COD dan TSS dengan uji Anava secara singkat, dimana dari hasil kandidat kadar PAC dari masing-masing variabel terwakili secara dengan kadar PAC yang dianggap efisien adalah 300 $\mathrm{mg} / \mathrm{l}$. Maka selanjutnya diuji perbedaan para kandiditat terseleksi tersebut seperti pda table 9 berikut ini.

Tabel 9. Kadar Penurunan Masing-masing Variabel BOD, COD dan TSS terseleksi dengan kadar PAC 75 mg/l

\begin{tabular}{lrrr}
\hline \multirow{2}{*}{$\begin{array}{l}\text { Waktu } \\
\text { Pemutaran }\end{array}$} & \multicolumn{4}{c}{ Kadar PAC (mg/l) } \\
\cline { 2 - 4 } & $\begin{array}{l}\text { PAC-300 } \\
\text { mg// } \\
\text { BOD }\end{array}$ & $\begin{array}{l}\text { PAC-300 } \\
\text { mg/l } \\
\text { COD }\end{array}$ & $\begin{array}{l}\text { PAC-300 } \\
\text { mg/l thd } \\
\text { TSS }\end{array}$ \\
\hline 10 Menit & 3800 & 7800 & $3,000.0$ \\
\hline 15 Menit & 3000 & 7200 & $2,500.0$ \\
\hline 20 Menit & 2800 & 6800 & $1,600.0$ \\
\hline 25 Menit & 2400 & 5600 & $1,000.0$ \\
\hline
\end{tabular}

Secara singkat tersebut singkat hasil akhir analisis tersebut adalah seperti pada table seperti pada tabel 10, berikut ini.

Tabel 10. Tabel Anova Satu Jalan Hasil Tes Variabel Dosis dan Waktu Pengadukan terhadap Penurunan Kadar TSS Pada Limbah Cair Tahu

\begin{tabular}{lrcrr}
\hline $\begin{array}{l}\text { Sumber } \\
\text { Varians }\end{array}$ & db & RJK & Fh & $\begin{array}{c}\text { Ftabel } \\
(\boldsymbol{\alpha}=\mathbf{0 , 0 5})\end{array}$ \\
\cline { 1 - 2 } $\begin{array}{l}\text { Antar } \\
\text { Kelompok }\end{array}$ & 2 & $90.034 .687,5$ & & \\
\cline { 1 - 2 } $\begin{array}{l}\text { Dalam } \\
\text { Kelompok }\end{array}$ & 9 & $3,044,375.0$ & & \\
\hline
\end{tabular}

Dari tabel 10 tergambar bahwa Fhitung > FTabel, dengan taraf signifikasi $0,05 \%$ dengan Derajat Kebebasan Antar Kelompok (Pembilang) yaitu $\mathrm{dk}=\mathrm{k}-1=3-1=2$, dan Varian dalam kelompok, $\mathrm{dk}=\mathrm{N}-\mathrm{k}=12-3=9$, maka $\mathrm{H} 0$ ditolak atau dengan kata lain ada perbedaan yang bermakna dari variansi kadar penurunan BOD, COD dan TSS tersebut. Oleh sebab itu dari Tabel 10 di atas kadar variabel yang dianggap efektif adalah dengan pemberian PAC $300 \mathrm{mg} / \mathrm{l}$ adalah waktu pengadukan 25 menit.

\section{PEMBAHASAN}

Penelitian ini mengamati faktor yang mempengaruhi kadar BOD, COD dan TSS dangam pengolahan limbah cair tahu secara Koagulasi dan Flokulasi menggunakan koagulan PAC (Pollyalumunium Chloride). Faktornya adalah dosis dan waktu pengadukan lambat. Dalam penelitian ini PAC (Pollyalumunium Chloride) yang ditambahkan pada limbah cair tahu dengan dosis $75 \mathrm{mg} / \mathrm{l}, 150 \mathrm{mg} / \mathrm{l}, 225 \mathrm{mg} / \mathrm{l}$ dan $300 \mathrm{mg} / \mathrm{l}$, waktu pengadukan lambat 10 menit, 15 menit, 20 menit dan 25 menit, dengan BOD (Biological Oxygen Demand) adalah banyaknya oksigen dalam $\mathrm{mg} / \mathrm{l}$ yang dibutuhkan dalam kondisi khusus untuk menguraikan benda organik secara Biologi. COD (Chemical Oxygen Demand) juga menentukan jumlah oksigen secaca kimiawi, yang dibutuhkan oleh bahan oksidan misalnya kalium dikromat untuk mengoksidasi bahan-bahan organik yang terdapat dalam air. Angka COD merupakan ukuran bagi pencemaran air oleh zat-zat organik, yang secara alamiah dapat dioksidasi melalui proses mikrobiologis dan mengakibatkan kurangnya DO (Disolved Oxygen) dalam air. Sedangkan TSS (Total Suspended Solid) adalah padatan yang menyebabkan kekeruhan air, tidak terlarut dan tidak dapat mengendap langsung. Padatan tersuspensi akan mengurangi penetrasi sinar/cahaya kedalam air sehingga mempengaruhi regenerasi oksigen secara fotosintetis, tingginya kadar TSS berpengaruh pada rendahnya DO (Disolved Oxygen).

Secara umum terjadi penurunan parameter limbah cair industri tahu (BOD, COD san TSS) sebelum dan sesudah pemberian pemberian PAC (Pollyalumunium Chloride), dengan variansi dosis dan waktu pengadukan. Penurunan kadar BOD misalnya sampai minimal $42,6 \%$ (waktu penadukan 10 menit) dan maksimal $70,7 \%$ (waktu penadukan 25 menit). Kadar COD minimal mencapai $0,86 \%$ (waktu pengdukan 10 menit) dan maksimal 36,36\% waktu penadukan 25 menit). Demikian pula kadar TSS, minimal $5,66 \%$ (waktu pengdukan 10 menit) dan maksimal $85,48 \%$, dengan waktu pengadukan 25 menit. Dimana kadar pemberian PAC yang diaksud di atas, yaitu kadar minimal $75 \mathrm{mg} / \mathrm{L}$ dan kadar maksimal 300 mg/L. 
Hasil Pemeriksaan Kadar BOD, COD dan TSS pada Penambahan PAC (Pollyalumunium Chloride).

\section{Pengaruh Variabel Dosis terhadap Penurunan Kadar BOD}

Hasil pemeriksaan awal BOD didapatkan kadar sebesar 8600 ppm, ini tentunya sudah melebihi nilai ambang batas yang sudah ditetapkan Baku Mutu Air Limbah Kegiatan Pengolahan Kedelai Menurut Peraturan Menteri Lingkungan Hidup No 5 tahun 2014, yang menyatakan bahwa BOD yang diperbolehkan yakni $150 \mathrm{ppm}$, setelah dilakukan pengolahan secara koagulasi dengan penambahan koagulan PAC (Pollyalumunium Chloride) secara umum kadar BOD berdasarkan dosis penambahan PAC (Pollyalumunium Chloride) tanpa memperhitungkan waktu pengadukan yang diberikan hasil kadar BOD setelah penambahan dosis sebesar $300 \mathrm{mg} / \mathrm{l} \mathrm{kadar}$ BOD sebesar 3600 ppm dengan persentase penurunan $58,13 \%$ Sedangkan penurunan terbesar terdapat pada dosis $300 \mathrm{mg} /$ ldengan kadar BOD sebesar 2400 ppm dengan persentase penurunan 72,09\% .

Pada penelitian ini Tabel 4.7 diatas dapat disimpulkan bahwa semakin tinggi dosis koagulan PAC (Pollyalumunium Chloride) yang diberikan semakin besar penurunan kadar BOD limbah cair tahu $(300 \mathrm{mg} / \mathrm{L}$ dengan waktu pengadukan 25 menit). Dengan demikian untuk mencapai Kadar Baku Mutu BOD Menurut Peraturan Menteri Lingkungan Hidup No 5 tahun 2014 yaitu $150 \mathrm{mg} / \mathrm{L}$, maka kadar yang efektif diperlukan $690 \mathrm{mg} / \mathrm{L}$ PAC.

\section{Pengaruh Variabel Dosis terhadap Penurunan Kadar COD}

Hasil pemeriksaan awal COD didapatkan kadar sebesar 8900 ppm, ini tentunya sudah melebihi nilai ambang batas yang sudah ditetapkan Baku Mutu Air Limbah Kegiatan Pengolahan Kedelai Menurut Peraturan Mentri Lingkungan Hidup No 5 tahun 2014, yang menyatakan bahwa COD yang diperbolehkan yakni $300 \mathrm{ppm}$, setelah dilakukan pengolahan secara koagulasi dengan penambahan koagulan PAC (Pollyalumunium Chloride) secara umum kadar COD berdasarkan dosis penambahan PAC (Pollyalumunium Chloride) tanpa memperhitungkan waktu pengadukan yang diberikan hasil kadar COD setelah penambahan dosis sebesar $300 \mathrm{mg} / \mathrm{l}$ kadar COD sebesar 6600 ppm dengan persentase penurunan $25,85 \%$ Sedangkan penurunan terbesar terdapat pada dosis 300 mg/ldengan kadar COD sebesar 5600 ppm dengan $37,07 \%$.

Pada penelitian ini Tabel 4.7 diatas dapat disimpulkan bahwa semakin tinggi dosis koagulan PAC (Pollyalumunium Chloride) yang diberikan semakin besar penurunan kadar COD limbah cair tahu $(300 \mathrm{mg} / \mathrm{l}$ dengan waktu pengadukan 25 menit). Dengan demikian untuk mencapai Kadar Baku Mutu COD Menurut Peraturan Menteri Lingkungan Hidup No 5 tahun 2014 yaitu $300 \mathrm{mg} / \mathrm{L}$, maka kadar yang efektif diperlukan $765 \mathrm{mg} / \mathrm{L} \mathrm{PAC}$.

\section{Pengaruh Variabel Dosis terhadap Penurunan Kadar TSS}

Hasil pemeriksaan awal TSS didapatkan kadar sebesar 7100 ppm, ini tentunya sudah melebihi nilai ambang batas yang sudah ditetapkan Baku Mutu Air Limbah Kegiatan Pengolahan Kedelai Menurut Peraturan Mentri Lingkungan Hidup No 5 tahun 2014, yang menyatakan bahwa TSS yang diperbolehkan yakni 200 ppm, setelah dilakukan pengolahan secara koagulasi dengan penambahan koagulan PAC (Pollyalumunium Chloride) secara umum kadar TSS berdasarkan dosis penambahan PAC (Pollyalumunium Chloride) tanpa memperhitungkan waktu pengadukan yang diberikan hasil kadar TSS setelah penambahan dosis sebesar $75 \mathrm{mg} / \mathrm{l}$ kadar TSS sebesar 2000 ppm dengan persentase penurunan $71,83 \%$ Sedangkan penurunan terbesar terdapat pada dosis $300 \mathrm{mg} / \mathrm{l}$ dengan kadar TSS sebesar 1000 ppm dengan persentase penurunan 85,91\%

Pada penelitian ini Tabel 4.7 diatas dapat disimpulkan bahwa semakin tinggi dosis koagulan PAC (Pollyalumunium Chloride) yang diberikan semakin besar penurunan kadar TSS limbah cair tahu $(300 \mathrm{mg} / \mathrm{l}$ dengan waktu pengadukan 25 menit). Dengan demikian untuk mencapai Kadar Baku Mutu TSS menurut Peraturan Menteri Lingkungan Hidup No 5 tahun 2014 yaitu $200 \mathrm{mg} / \mathrm{L}$, maka kadar yang efektif diperlukan 540mg/L PAC.

Pengadukan pelan akan memperpendek jarak antar partikel sehingga gaya tarik menarik antar partikel menjadi lebih besar dan dominan dibandingkan gaya tolakannya yang menghasilkan kontak dan tumbukan antar partikel yang lebih banyak dan lebih sering. Kontak inilah yang menggumpalkan partikelpartikel padat terlarut terkoagulasi berukuran mikro menjadi partikel-partikel flok yang lebih besar. Flok-flok ini kemudian akan beragregasi. Ketika pertumbuhan flok sudah cukup maksimal (masa, ukuran) flok-flok ini akan mengendap ke dasar reservoir, sehingga terbentuk dua lapisan 
pada reservoir, yaitu lapisan air jernih pada bagian atas reservoir dan lapisan endapan flok yang menyerupai lumpur pada dasar reservoir (Karamah, 2008).

\section{Pengaruh Variabel Dosis terhadap Penurunan Kadar BOD, COD dan TSS secara Keseluruhan}

Dosis PAC yang efektif dan efisien terhadap pengaruh kesemua variabel BOD, COD dan TSS dengan waktu pengadukan 25 menit tersebut untuk mencapai standar baku mutu seperti pada Peraturan Menteri Lingkungan Hidup No 5 tahun 2014. Penambahan waktu pengadukan pelan akan menaikkan efektivitas koagulasi hingga dicapai waktu pengadukan pelan yang optimum, dimana pertumbuhan flok sudah mencapai titik maksimalnya. Maka dapat disimpulkan bahwa waktu pengadukan lambat 25 menit efektif dalam menurunkan kadar TSS dengan persentase penurunan sebesar $74,97 \%$. (Kementerian Lingkungan Hidup, 2014).

\section{SIMPULAN}

1. Terjadi penurunan kadar variabel baik BOD, COB dan TSS, baik dari variansi dosis PAC mulai dari $75 \mathrm{mg} / \mathrm{l}, 150 \mathrm{mg} / \mathrm{l}, 225 \mathrm{mg} / \mathrm{l}$ dan $300 \mathrm{mg} / \mathrm{l}$ maupun variansi pengadukan masing-masing 10, 15, 20 dan 25 menit,

\section{DAFTAR PUSTAKA}

Asmadi dan Suharno. 2012. Dasar-dasar Teknologi Pengolahan Air Limbah. Yogyakarta: Gosyen Publishing.

Karamah, E. F., \& Septiyanto, A. 2008. Pengaruh suhu dan tingkat keasaman $(\mathrm{pH})$ pada tahap pralakuan koagulasi (koagulan aluminum sulfat) dalam proses pengolahan air menggunakan membran mikrofiltrasi polipropilen hollow fibre. Jurnal Teknologi, 12(1).

Kementerian Lingkungan Hidup. 2014. Peraturan Menteri Lingkungan Hidup Nomer 5 Tahun 2014 Tentang Baku Mutu Air Limbah.

http://175.184.234.138/sipil/application/up loads/Baku_Mutu_Air_LimbahPermen_L

H_No.5_Tahun_2015.pdf (Diakses pada 04 Januari 2017).

Kristijarti, A. P., Suharto, I., \& Marieanna, M. 2013. Penentuan Jenis Koagulan dan Dosis Optimum untuk Meningkatkan Efisiensi Sedimentasi dalam Instalasi Pengolahan
2. Hasil uji perbedaan tidak terjadi perbedaan yang bermakna, maka peranan pemberian PAC dengan kadar. $300 \mathrm{mg} / \mathrm{l}$ menjadi pilihan.

3. Kadar sebelum pemberian PAC (kadar sampel) dari semua variabel sudah tinggi, jauh di atas ambang batas baku mutu, sehingga penurunannya untuk semua variabel mencapai baku mutu, PAC yang diperlukan $765 \mathrm{mg} / \mathrm{l}$,dengan waktu pengadukan 25 menit.

\section{SARAN}

1. Pemerintah Daerah Kota Bandar Lampung melalui sector terkait agar memerintahkan para perajin tahu untuk membangun instalasi pengolahan air limbah tahu, berkelompok (komunal) untuk menghemat biaya, karena air limbah industri tahu tersebut sudah jauh diatas kadar baku mutu baik BOD, COD maupun TSS.

2. Instalasi dimaksud adalah istalasi melalui minimal lima tahapan yaitu a) bak Pemisah Lemak, b) Bal Ekualisasi, c) Bak Koagulasi, d) Bak Flokulasi dan e) Bak Sedimentasi,.

3. Bagi Politeknik Kesehatan Tanjungkarang, agar penerapan ilmu dan teknologi pengolahan limbah cair industri tahu ini di lapangan, dapat dijadikan bahan pengabdian masyarakat bagi dosen maupun mahasiswa.

Air Limbah Pabrik Jamu X. Research Report-Engineering Science, 2.

Mirzaiy, A. dkk. 2012. Removal Turbidity, Organic Matter, Coliform and Heterotophic Bacteria by Coagulants Poly Alumunium Chloride from Karoon River in Iran. Asian Journal Chemistry; Vol. 24, No, 6 (2012) p. 2389-2393.

Moorthy, D.V.S., dan Babu, R. 2010. Removal COD of Reactive Dyes Using Poly Alumunium Chloride. ARPN Journal of Engineering ang Applied Sciences, Vol. 5, No. 6, June 2010, p 10-22.

Nansubunga, I., dkk. 2013. Effect of Polyalumunium chloride water treatment sludge on effluent quality of domestic waste water treatment. African Journal of Enviromenta Science and Technology, Vol. 7(4) April 2013, P. 145-152.

Notoadmodjo, S. 1993. Metode Penelitian Kesehatan. Jakarta: Rineka Cipta. 
Sadzali, I. 2010. Potensi limbah tahu sebagai biogas. Jurnal UI Untuk Bangsa Seri Kesehatan, Sains, dan Teknologi, 1(12), 62-69.

Supriyadi. 2014. Statistik Kesehatan. Jakarta: Salemba Medika.
Wang, J. dkk. 2014. Compatison of Three Alumunium Coagulants for Phosphorus Removal. Journal of Water Resource and Protection, 6, p. 902-908. 